\title{
The determinants of ownership in M\&As: An analysis of the stake purchases in Romanian acquisitions
}

\author{
George Marian Aevoae ${ }^{\mathrm{a}, 1}$, Roxana Dicu ${ }^{\mathrm{a}}$, Daniela Mardiros ${ }^{\mathrm{a}}$ \\ ${ }^{a}$ Alexandru Ioan Cuza University of Iasi, Romania
}

\begin{abstract}
Research question: The study aims to identify the microeconomic factors that influence the amount of stake purchased in Romanian acquisitions. Motivation: Romania is a market with potential and one of the fastest growing economies in the European Union, facts that make Romanian companies appealing for this type of restructuring transactions. Thus, Romanian companies participate in acquisitions, being either in the position of acquirers or target entities (in most cases). We want to identify if the purchased stake is significantly influenced by a series of factors, related to both involved companies. Idea: The decision of an acquirer to purchase a stake in a target company depends on both its characteristics and the ones of the target company which meets its needs. Considering this assumption, we use a series of financial and nominal factors, which are related to both companies involved (productivity and workforce ratios, the relatedness between the activities of the companies involved and the national/international dimension on the investment), to estimate how much they influence the purchased stake in Romanian acquisitions. Data: The study is based on a sample of 192 acquisitions, with one target and one acquirer, in which a Romanian company was involved, for 2010-2017 period of time. Out of these, 130 transactions are industry acquisitions and 62 transactions are services acquisitions. Tools: We use linear regression, crosstabulation and ANOVA. Findings: Using a mediation model, the results will show that the workforce ratio, the productivity ratio and the relatedness of the two companies have a significantly influence in the percentage purchased in the target company, but the national/international side of the M\&As lead to an increase in the capacity of the
\end{abstract}

${ }^{1}$ Corresponding author: Department of Accounting, Business Information Systems and Statistics, "Alexandru Ioan Cuza" University of Iasi, Romania; Carol I Blvd no. 22; tel. +40752774447; e-mail address: aevoae@gmail.com 
proposed models to predict the variance of the final investment. The results are controlled for industry and services, considering the NACE main section of the target company. Contribution: Our findings contribute to the scarce literature on Romanian acquisitions, providing information regarding the influence factors on the purchased stake in acquisitions.

Keywords: acquisitions, ownership, relatedness, determinants, stake.

JEL codes: G34, M16, M21

\section{Introduction}

The consequences of M\&As on the performance of entities involved in these transformation processes have been and still represent a key point of interest for both practitioners and economic researchers (Bouchikhi \& Kimberly, 2012; Rani et al., 2015). There are many approaches that explain why M\&As occur. In the literature, in most cases, the motivation of the management of the acquiring company and the shareholders of the target company are mostly taken into account, the consequences on other stakeholders being considered on a considerably lower measure. This could be explained by the fact that the decision to enter into a M\&A depends on the management of the two companies, but also on the investors of the target company.

The M\&A experience may appear difficult and life-changing for the involved entities and their stakeholders, but it is familiar to those who have been already through this process. Also, it illustrates why there is need for a new M\&A math, which should expand from a simple efficiency calculation to a new dimension: for one plus one to make more than two at the economic level, one plus one must make one at the psychological level. When M\&As fail to deliver promised levels of performance, as frequently occurs, it is likely due at least in part to a lack of psychological synergies (Bouchikhi \& Kimberly, 2012). That is why the employee component in any M\&A should be of great importance for both the management and the investors, with a special emphasis on the number of employees each company brings into the concentration.

The concept of value creation through mergers and acquisitions is highlighted both in the literature and in the practice of companies by assessing it, on the one hand, for the acquirer and, on the other hand, for the target company. In this context, it is of great importance to establish the report between the productivity of the two companies, in the pre-M\&A phase, in order to establish the stake which is to be purchased in the concentration. Later, after the integration stage, the same information could be used as a benchmark for the efficiency gains and M\&A success, 
as increases in revenues or economies of costs (Rozen-Bakher, 2018; Frazer \& Zhang, 2009; Devos et al., 2009). M\&A studies underline the fact that, in the postM\&A phase, the creation of value is particularly evident in the target companies, the shareholders of the acquiring entities remaining, at best, in the situation where they were in the pre-M\&A phase (Canina et al., 2010, Jensen \& Ruback, 1983; Andrade et al., 2001).

In the case of mergers and acquisitions, researchers and practitioners often invoke the umbrella term, M\&As, when they actually refer to only just one of them. In Romania, there is a clear difference between them, from a legal, procedural and accounting point of view. However, many studies don't make a difference between them, especially in managerial approaches (Brătianu \& Anagnoste, 2011; CernatGruici et al., 2008). The studies that are focused mainly on acquisitions are the ones that are based on study events methodology, e.g. abnormal returns (Pop, 2006; Filip et al., 2018).

Companies perform acquisitions for various reasons, so, in this study, we discuss a series of variables that may influence a company's decision to involve in this type of transactions and the size of the investment, on Romanian market. A company may seek to achieve economies of scale, greater market share, increased synergy, cost reductions, or new niche offerings, all of them resulting in synergy success or efficiency gains. All these start from the purchase of a specific stake in a target company that fulfils the needs of the acquirer. Starting from these premises, the present study intends to estimate the influence of efficiency indicators (productivity ratios), workforce indicators (employee ratios) and a number of qualitative characteristics of the target company on the percentage of shares, purchased by an acquirer in an acquisition which involves at least one Romanian company. Thus, we intend to validate a model which assesses the influence of some determinants on the stake purchased, for the case of Romanian acquisition market.

\section{Literature review and hypotheses development}

Acquisitions, as world recognized expansion strategies, account for almost half of the worldwide M\&As, but one thing that matters the most in this assessment is the level of equity (stake) that the executives of the acquirers decide to purchase in the target companies.

\subsection{A taxonomy of acquisitions}

The two main categories involved in negotiating and closing an acquisition are investors of the companies and their managers, other stakeholders having little influence in the process. The position in the company of the two mentioned 
categories and their responsibilities determine specific roles in the acquisition phases (discovery, due diligence, agreement and announcement, integration, and sustainable performance) (Schuster \& Hunter, 2015). Starting from Easterbrook's (1984) opinion, that the investors have ownership without control and the managers have control without ownership, a classification of acquisitions can be discussed.

Both mergers and acquisitions can be negotiated by the management, having the approval of the target's Board of Directors, or may result from offers made directly to the shareholders of the target company (Knoeber, 1986). When discussing a possible classification of acquisitions, in theory and practice, the most common structures are negotiated or friendly acquisitions (the acquiring entity announces the Board of Directors about the intention to acquire the target company, which approves the transaction), and hostile takeovers (Irfan, 2010). From managers point of view, both negotiated M\&As and hostile ones leave one team of managers (out of two) in control of the new company and its assets. This represents the visible consequence of competition for control, and the victory should belong to the managers that can use the assets at their best (Easterbrook, 1984).

In the case of acquisitions, the management of the two companies needs to be further discussed because they do not require financial or performance changes, from an accounting point of view. Acquisitions only cause changes in the shareholder structure of the target company. There are three possibilities that conduct to takeovers.

The first one is the situation in which the acquiring company's management buys the titles of the existing shareholders, offering prices which include a high premium (tender offers). The tender offers are transactions which don't benefit from the approval of the target's Board of Directors. Shleifer and Summers (1988) have argued that the large premiums received by corporate shareholders derive from the improved management and increased efficiency brought about by restructurings. Historically, tender offers were an easy way to acquire a company, being an effective corporate governance mechanism, used as a takeover device to bypass an unreceptive board of directors (Offenberg \& Pirinsky, 2015).

In the second case, the acquirers change the management of the target company, using a simple majority of company's shareholders willing to vote for that change (proxy fight). The management of the acquiring company uses the negotiation power of proxy voting (a person or a company are representatives of a shareholder and they carry the right of voting in the absence of the owner of the titles). The new management votes for the acquisitions.

In the third case, the acquirers pursue and purchase the securities put on sale by the target company on capital markets (Suzuki, 2015). In many cases the new securities represent the initial public offering (IPO) of the target company. Casares Field and 
Karpoff (2002) discuss the importance of takeover defenses when target companies go public although, in many cases, there isn't a preoccupation for deploying such actions (Easterbrook \& Fischel, 1991). The presence of defense mechanisms lowers the value of the IPO firm and does not lead to high takeover premiums. Thus, the firms that go public are easy to be acquired because they don't use, in the first place, the most common takeover defenses (poison pill securities or staggered boards, the latter being also an effective mechanism against proxy fighting). Using a complete opposite approach, Lehmann and Schwerdtfeger (2016) consider that takeovers of IPO firms it's actually a win-win situation, especially in the case of small companies which fall under market for corporate control theory.

According to Irfan (2010), in vertically differentiated industries, in equilibrium, target's executives keep low level of R\&D and advertising expenditures to make their firm an unattractive target for hostile takeovers.

Although, in most cases, the acquiring company is the one who imposes the rules in the post-concentration integration period, in the case of reverse acquisitions, the acquiring entity undergo major changes imposed or determined by the target company (Denison et al., 2011). Another special situation is the one of the backflip acquisitions, in which the target company turns, post-acquisition, into a subsidiary of the acquiring company (Di Laurea, 2014: 9).

In this context, it is necessary to analyze the concentration in terms of expected benefits, taking into account the elements that have the potential to generate them, to the detriment of those that theoretically should lead to such a situation. We have in mind the cost of implementing change measures, the quantifiable economic benefits resulting from the implementation of the measures, the time horizon in which they are expected to be achieved, and the negative synergies that may result from the conclusion of the transactions. Thus, the premium becomes a consequence of the M\&A and reflects the reality of the transaction if these elements are realistically established. Payment of a specific premium reflecting the expected synergy value does not provide any guarantee in this respect; in fact, the acquirer pays for an opportunity to achieve synergy (Ficery et al., 2007).

\subsection{Qualitative and quantitative determinants in acquisitions}

The synergies in both mergers and acquisitions can be related to activities and to employees. Traditionally, the scientific literature focused mainly on strategic and financial factors but, recently, more studies have explored the socio-cultural and human resources factors (Rizen-Bakher, 2018). Anyway, a restructuring operation is primarily based on efficiency gains and economic value creation for the involved shareholders, more than on the well-being of the employees, the latter having a strong managerial side difficult to quantify. 
A fundamental difference between real assets and human capital is that real assets can be purchased, while human capital is rented (Lee et al., 2018), so there are few ways in which it can be measured. From an accounting point of view, the annual reports of the companies present the average number of employees per year and the cost of employees, next to other information related to pensions, incentives and other benefits. In the context, in M\&As, productivity related to employees can be calculated as ratios between accounting figures and the number of employees: revenues per employee (Rozen-Bakher, 2018), assets per employee and income per employee (Frazer \& Zhang, 2009; Kumar \& Suhas, 2010) or capital per employee (Bandick \& Görg, 2010). Also, the number of employees brought by each company in the concentration can be representative for the calculation of a workforce ratio (Rozen-Bakher, 2018; Bandick \& Görg, 2010).

In the pre-M\&A phases, such as due diligence and negotiation, the number and location of employees, salaries and benefit structure are hard facts that influence the decision to participate in M\&As (Schuster \& Hunter, 2015). After the decision is made, the report between the number of employees of the involved companies is an indicator that can influence the purchased stake (Rozen-Bakher, 2018).

Conyon et al. (2000) assert that M\&A behavior inevitably leads to, and indeed is motivated by, the possibility of drastically downsizing the workforce. In both cases, it is difficult to retain and redeploy the combined firms' workforces or layoff duplicate and/or less productive workers (Lee et al., 2018). There is a wealth of information that will help organizational leaders develop a cost-benefit model for a M\&A and project the intangible costs and benefits associated with the people factor. As with any significant change, destabilization of the workforce can result in a decline of performance characterized by losses in productivity, revenue, opportunities, retention, extensive costs of hiring and replacement. Ideally, these declines will correct themselves, and the gains will show, as integration progresses, and sustainable performance are achieved.

Thus, each of the companies comes into the M\&A with its own employees, but, in integration phase and later, it can be an endeavor to realize human capital synergies.

The human capital synergy success can be analyzed taking into account the combination of skills, abilities and knowledge of employees brought by each company in the concentration. In other cases, it emerges from the combined competences of a group as a result of the learning process resulting from previous interactions within the group (Harrigan et al., 2016). Other studies have pointed out that organizational cultural differences increase post-concentration conflicts, if they appear as a result of M\&As (Sarala, 2010; Sarala \& Vaara, 2009; Stahl \& Voigt, 2008) for several reasons, including identities conflict that lead to inter-group stigma (Cartwright \& Schoenberg, 2006), ambiguity in values and practices, distrust and lack of cooperation, as the rise of the inter-group conflict leads to alienation, stress, anger, low engagement and detachment (Weber et al., 2011). Panchal and Cartwright 
(2001) state that the employees from the acquired company or smaller M\&A partner may be confronted with more stress because they face longer and more negative change. The authors Blackard and Gibson (2002) propose the term productive synergy, the result of a situation in which the conflict of opinion between employees leads to solutions. The only condition is that the individuals involved (employees, employers) share the differences and learn from them. As a consequence, the expected economic synergies must be preceded and combined with the psychological ones. There is a collective effect on employee psychological synergies of three different relationship. First one is the relationship between the employee and the new organization, which underlines the importance of employee identification with and commitment to post-M\&A organizational strategy and goals. The second relationship settles between the employee and its supervisor/manager, representing the extent to which a supervisor delegates and gives autonomy to employees. The last relationship that greatly influence employees' assessments of their jobs is the employee-co-worker relationship (Alegre et al., 2016).

Both economic and psychological synergies depend a lot on the degree of relatedness between the core activities and the assets put together by the involved companies. It is easier to put together two companies that develop similar activities than to put together activities from totally separated industries. This dissociation is also reflected on the attitude of employees on a side and on the capacity of the assets to be put at work so the income to increase.

The concept of relatedness is very discussed in the M\&A literature, being associated to both the assets involved and the core activities of the companies. In the opinion of King et al. (2004), the relatedness between target companies and their acquirers can be related to resources or product-market similarity. Canina at al. (2010) consider that the relatedness of assets is more obvious for the horizontal M\&As, then in any other case (vertical and conglomerate). Considering M\&As, Hagerdoorn and Duysters (2010) consider relatedness in terms of relationship: they believe that horizontal/vertical M\&As are made between related companies, while conglomerate M\&As are between unrelated companies. Cefis and Rigamonti (2013) consider that the industry relatedness does not occur randomly, but it is, in fact, one of the main aspects that an acquirer must take into consideration before pursuing a M\&A. According to Fan and Lang (2000), two business can be classified as unrelated if they do not share the same two-, three-, or four-digit code of the national classification of economic activities, and vice-versa. This last approach was the one used to describe the relationship between the two companies.

In this context, we propose to test and validate the following hypotheses:

$\mathrm{H}_{1}$ : The investment decision of an acquirer to purchase a certain amount of stake in a target company is positively influenced by the industry relatedness, productivity ratio, and workforce ratio. 
Globalization is a catchy term and researchers from economic deployment field presented their opinion regarding it, including in studies related to M\&As (Nitzan, 2001; Norbäck \& Persson, 2008; Warter \& Warter, 2014). Although the time has passed, it still continues to be an arguable phenomenon, which brings advantages and, along with them, disadvantages. Globalization has, as main effect, like Thomas L. Friedman (2005) suggested in the title of his book, the fact that "the world is flat", without frontiers. Globalization, amongst others, is the process by which economic entities develop international influence or, even start operating on international scale. M\&As offer the best tools for external economic growth and, in Europe, countries from within the European Union (EU) have all the strengths and opportunities in this respect. Companies, by combining their activities, may allow the development of new products more efficiently, reduce production or distribution costs. In this context, "the market becomes more competitive and consumers benefit from higherquality goods at fairer prices" (European Commission, 2013). Even though some M\&As may reduce competition in a market and harm consumers through higher prices, reduced choices or less innovation, this kind of transactions are being examined by the European Commission in order to prevent harmful effects on competition. In other words, increased competition within the European Union, the desire for a single market and the globalization constitute the main factors which make it attractive for companies to join forces.

We hypothesize that in acquisitions, another aspect of major importance, when analyzing the acquirer's choice for a company, the amount of stake purchased into a target is strongly influenced by the location of the target company. Thus, we can discuss about domestic and cross-border acquisitions. Cross-border acquisitions can be expected to be more complex, and thus more costly and risky to execute, than domestic acquisitions (Danbolt \& Maciver, 2012). Thus, a differentiation between the two types of acquisitions has a positive significant influence, as mediation variable, on the stake purchased in the target company.

$\mathrm{H}_{2}$ : The national/international dimension of the acquisitions is positively influencing the acquirer's decision to invest into a certain amount of stake in a target company.

These hypotheses will be tested and validated using the statistical software SPSS 25.0.

\section{Research methodology and design}

The study aims at analyzing the influence of the productivity and workforce ratios, the relatedness between the activities of the companies involved and of the national/international dimension on the investment made by the acquirers in the 
equity of the target companies, considering the example of Romanian M\&A activity, namely acquisitions.

\subsection{Target population and analyzed sample}

To test and to validate the proposed research hypotheses, the study analyses the empirical data related to 192 acquisitions, for the 2010 - 2017 period of time, in which at least one Romanian company is involved. Out of these, 130 transactions are industry acquisitions and 62 transactions are services acquisitions. According to EU, sections A-G from NACE Rev. 2 are associated to industry, sections H-U are composing the services. The data regarding the NACE main section for the target company are collected from Zephyr database, for the 2010-2017 period of time. The sample analyzed contains financial information for both the target and the acquirer company, this reduced the analyzed sample for the range of time taken into account. Also, the study considers only the 1:1 acquisitions (one acquirer and one target), with available deal values.

To reach the proposed research hypotheses, we use linear regression, cross tabulation and ANOVA.

\subsection{Models proposed for analysis and data source}

This paper examines a series of factors influencing the stake purchased in a target, considering the acquisitions made by Romanian companies, either in the position of acquirer or target, for the 2010-2017 period of time. The proposed variables are presented in Table 1.

Table 1. The variables proposed for the analysis

\begin{tabular}{|c|c|c|c|}
\hline Symbol & Representation & Description & Explanation \\
\hline Stake (S) & $\%$ & $\begin{array}{l}\text { Dependent } \\
\text { variable (DV) }\end{array}$ & $\begin{array}{l}\text { The percentage purchased } \\
\text { in the target companies } \\
(0.001-100 \%) \text {. } \\
\text { Information collected from } \\
\text { Zephyr database, for the } \\
2010-2017 \text { period of time. }\end{array}$ \\
\hline \multirow{2}{*}{$\begin{array}{l}\text { Workforce } \\
\text { ratio (Work_r) }\end{array}$} & Employees_acq $q_{t-1}$ & \multirow{2}{*}{$\begin{array}{l}\text { Independent } \\
\text { variable (IV)/ } \\
\text { numeric }\end{array}$} & The ratio is calculated \\
\hline & $\overline{\text { Employees_target }_{t-1}}$ & & $\begin{array}{l}\text { considering the number of } \\
\text { employees of the acquirer } \\
\text { and of the target company, } \\
\text { reported for the year before } \\
\text { the M\&A; information } \\
\text { collected from Orbis } \\
\text { database, for the 2010- } \\
2017 \text { period of time. }\end{array}$ \\
\hline
\end{tabular}

Vol. 18, No. 3 
The determinants of ownership in M\&As: An analysis of the stake purchases in Romanian acquisitions

\begin{tabular}{|c|c|c|c|}
\hline Symbol & Representation & Description & Explanation \\
\hline $\begin{array}{l}\text { Productivity } \\
\text { ratio(Prod_r) }\end{array}$ & $\frac{\frac{\text { Revenues_ac }_{t-1}}{\text { Employees_acq }_{t-1}}}{\text { Revenues_target }_{t-1}}$ & $\begin{array}{l}\text { Independent } \\
\text { variable (IV)/ } \\
\text { numeric }\end{array}$ & $\begin{array}{l}\text { The ratio is calculated } \\
\text { considering the operating } \\
\text { revenues per employee for } \\
\text { the acquirer and for the } \\
\text { target company, reported } \\
\text { for the year before the } \\
\text { M\&A; information } \\
\text { collected from Orbis } \\
\text { database, for the 2010- } \\
2017 \text { period of time. }\end{array}$ \\
\hline $\begin{array}{l}\text { Relatedness } \\
\left(\mathbf{R} \_ \text {UnR) }\right.\end{array}$ & $\begin{array}{l}\text { 1. Related acquisitions } \\
\text { 2. Unrelated } \\
\text { acquisitions }\end{array}$ & $\begin{array}{l}\text { Independent } \\
\text { variable (IV)/ } \\
\text { categorical }\end{array}$ & $\begin{array}{l}\text { Considering the NACE } \\
\text { Rev. } 2 \text { main codes for the } \\
\text { target and for the acquirer, } \\
\text { from the Orbis database, } \\
\text { the relatedness of the } \\
\text { involved companies was } \\
\text { completed by hand, } \\
\text { comparing the first two } \\
\text { digits of the NACE } \\
\text { primary code. }\end{array}$ \\
\hline $\begin{array}{l}\text { Domestic/Cross } \\
\text {-border M\&As } \\
\text { (Int) }\end{array}$ & $\begin{array}{l}\text { 1. Cross-border } \\
\text { acquisitions } \\
\text { 2. Domestic } \\
\text { acquisitions }\end{array}$ & $\begin{array}{l}\text { Mediation } \\
\text { variable/ } \\
\text { categorical }\end{array}$ & $\begin{array}{l}\text { The countries of the } \\
\text { acquirer and of the target } \\
\text { companies were } \\
\text { considered, information } \\
\text { collected from Zephyr } \\
\text { database, for the 2010- } \\
2017 \text { period of time. }\end{array}$ \\
\hline
\end{tabular}

Dependent variable. This variable represents the stake purchased by the acquirer in the target company. Thus, this variable is a percentage between $0.001 \%$ (shares in jointly controlled entities) and $100 \%$ (acquisition of a controlling interest).

Independent variables. The variables Workforce ratio and Productivity ratio are presented in Table 1 and they are calculated as a report between the data of the acquirer and the one of the target company, considering the financial information for the year before the acquisition. According to Rozen-Backer (2018), the data from the year before the concentration are specific to pre-acquisition stage and they are collected from Orbis database.

Mediation variable. The assumption of causality is implicit in the definition of mediation, as a mediator is defined as an explanatory mechanism through which one variable affects another (Wood et al., 2007). This variable is considered for the year of the merger, given the fact that there are studies which validated its significance in influencing a financial dependent variable (Moeller \& Schlingemann, 2005).

The proposed hypotheses are examined using mediation analysis, considering all acquisitions, industry acquisitions and services acquisitions. There are multiple ways 
to test a mediation model (Frazier et al., 2004; Wu \& Zumbo, 2008). When paths a and $\mathrm{b}$ are controlled, a previously significant relation between IV and DV is no longer significant (complete mediation) or its significance is dropping (partial mediation). In our case, the paths are presented in Figure 1:

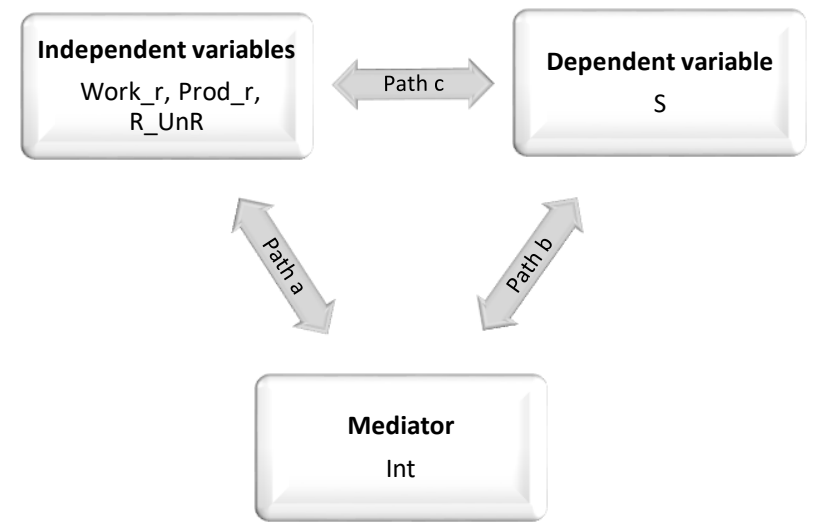

Figure 1. The proposed mediation model

Our mediation model includes the following steps, tested and validated for all acquisitions, and then separately for industry and services acquisitions:

1) path $c$ is predicting the DV from independent variables Work_r, Prod_r and $R_{-} U n R$ (without the mediator); the model is presented in Eq. (1):

$$
S(\%)=\alpha+\beta_{1} \cdot \text { Work_ } r+\beta_{2} \cdot \text { Prod_ } r+\beta_{3} \cdot R_{-} U n R+\varepsilon
$$

2) path $a$ is predicting the mediator Int from the independent variables Work_r Prod_r and $R_{-} U n R$; the model is presented in Eq. (2):

$$
\text { Int }=\alpha+\beta_{1} \cdot \text { Work_ } r+\beta_{2} \cdot \text { Prod_r }+\beta_{3} \cdot R_{-} U n R+\varepsilon
$$

3) path $b x c$ is predicting the DV from independent variables Work_r,Prod_r and $R \_U n R$ (including the mediator); the model is presented in Eq. (3):

$$
S(\%)=\alpha+\beta_{1} \cdot \text { Work_ } r+\beta_{2} \cdot \text { Prod_r } r+\beta_{3} \cdot R_{-} U n R+\beta_{4} \cdot \text { Int }+\varepsilon
$$

The used method is hierarchical linear regression (HLR) because it is a way to show if variables of our interest explain a statistically significant amount of variance in our DV after accounting for all other variables. Also, our study includes variance inflation factor (VIF), to identify multicollinearity problems. The VIF and tolerance are both widely used measures of the degree of multi-collinearity of the $i^{\text {th }}$ independent variable with the other independent variables in a regression model (O'Brien, 2007) and it has three accepted thresholds: if VIF is higher than 3, than the probability for multicollinearity increases, when VIF is higher than 5 , there is most probable to have collinearity and, in case VIF is higher than 10 , the collinearity exists for sure. 


\section{Results and discussions on the influence of specific determinants on the purchased stake in a target company}

Romania is a market with potential, a strategic location, and a favorable business climate as the International Trade Administration (2018) states, despite its weaknesses. Although Romania overthrew its communist regime more than 28 years ago, the government still plays an oversized role in the economy in terms of employment, ownership of assets, and influence on the business environment. After joining the EU in 2007, Romania made some progress, even though companies still report challenges and poor infrastructure which continue to negatively impact business costs, productivity, public safety and the ability to attract FDI. In these particular conditions, its economy is among the EU's fastest growing: $4.8 \%$ growth in 2016 and $6.9 \%$ in 2017 (the highest since 2008) (International Trade Administration, 2018). This growth is primarily consumption-based, which makes Romania an open market, in which companies try to be competitive when selling their product. A downsize in this case is that it allows bigger companies to enter the Romanian market and small economic entities to struggle for survival due to fiscal and tax policy, wages and pension increases. The Index of Economic Freedom (2018) presents Romania as $42^{\text {nd }}$ freest economy, with a score of 68.6 , situated between Malta $\left(41^{\text {st }}\right)$ and Thailand $\left(43^{\text {rd }}\right)$, the first positions being occupied by Hong Kong, Singapore and New Zealand.

The case of Romania, regarding M\&As before 2007 January $1^{\text {st }}$ and after the adherence date, is presented in Table 2 .

Table 2. The evolution of 22 years of Romanian M\&A activity

\begin{tabular}{lllllll}
\hline Year $M \& A s$ & $\mathbf{1 9 9 7}$ & $\mathbf{1 9 9 8}$ & $\mathbf{1 9 9 9}$ & $\mathbf{2 0 0 0}$ & $\mathbf{2 0 0 1}$ \\
\hline $\begin{array}{l}\text { No. } \text { of } M \& A s \\
\text { Deal value } \\
\text { (Th. euro) }\end{array}$ & 7 & & 10 & 20 & 45 & 28 \\
$\quad \mathbf{2 0 0 2}$ & $\mathbf{2 0 0 3}$ & $\mathbf{2 0 0 4}$ & $\mathbf{2 0 0 5}$ & $\mathbf{2 0 0 6}$ & $\mathbf{2 0 0 7}$ \\
99 & 88 & 99 & 153 & 152 & 184 \\
$728,637.27$ & $1,053,248.20$ & $2,516,471.60$ & $3,203,348.88$ & $2,125,434.47$ & $1,663,429.06$ \\
$\mathbf{2 0 0 8}$ & $\mathbf{2 0 0 9}$ & $\mathbf{2 0 1 0}$ & $\mathbf{2 0 1 1}$ & $\mathbf{2 0 1 2}$ & $\mathbf{2 0 1 3}$ \\
175 & 137 & 228 & 177 & 282 & 402 \\
$5,713,521.04$ & $981,255.40$ & $777,373.71$ & $55,839.05$ & $1,147,656.68$ & $1,963,394.08$ \\
$\mathbf{2 0 1 4}$ & $\mathbf{2 0 1 5}$ & $\mathbf{2 0 1 6}$ & $\mathbf{2 0 1 7}$ & $\mathbf{2 0 1 8}$ & Total \\
538 & 279 & 355 & 570 & 521 & 4,549 \\
$3,389,609.98$ & $1,780,199.64$ & $1,852,315.16$ & $9,376,784.09$ & $2,509,212.56$ & $46,436,134.1$ \\
\hline
\end{tabular}

(Source: Authors' own processing, using Zephyr database (1997-2018))

The information presented in Table 2 reflects all the M\&A activity in Romania, with available deal value and completion date, collected from Zephyr database. Romanian M\&As notice an increasing trend in the number of transaction and/or deal value, in the 1997-2018 period of time. In a separate study, we identified that a large number of transactions and a low deal value is due to the fact that foreign companies are interested in small companies which apply local GAAP, thus they cost less than a company which applies IFRS (Aevoae \& Georgescu, 2019). 
The study will present a series of descriptive statistics for the analyzed variables (per total and on categories considered in the analysis), including the ANOVA for the stake, considering the national/international dimension of the acquisitions and the relatedness between the companies, of the values of the Pearson correlation coefficients and the estimations of the parameters of the proposed regression models.

The ANOVA results, presented in Table 3, show significant difference between the means of the purchased stakes in the target companies, considering two groups of transactions: transactions which involved related/unrelated companies and transactions in which the two companies are located in Romania or one is in Romania and the other one is located in a different residence country.

Table 3. The ANOVA for the categorical variables considering the purchased stake

\begin{tabular}{|c|c|c|c|c|}
\hline Categories & Number & Mean & $\begin{array}{c}\text { Std. } \\
\text { Deviation }\end{array}$ & $\begin{array}{c}\text { F-ratio } \\
\text { and p-value }\end{array}$ \\
\hline $\begin{array}{l}\text { Unrelated } \\
\text { acquisitions }\end{array}$ & 124 & 44.60841 & 39.981670 & $\begin{array}{c}\mathrm{F}(1,190)=24.240 \\
\text { Sig. }=.000\end{array}$ \\
\hline Related acquisitions & 68 & 73.39268 & 36.338841 & \\
\hline $\begin{array}{l}\text { Domestic } \\
\text { acquisitions }\end{array}$ & 132 & 43.73435 & 38.819639 & $\begin{array}{c}\mathrm{F}(1,190)=36.452 \\
\text { Sig. }=.000\end{array}$ \\
\hline $\begin{array}{l}\text { Cross-border } \\
\text { acquisitions }\end{array}$ & 60 & 79.15352 & 35.010701 & \\
\hline Total & 192 & 54.80284 & 41.026130 & \\
\hline
\end{tabular}

Regarding the nominal variables used in the models (relatedness and the national/international dimension of the Romanian acquisitions), the cross tabulation is presented in Table 4.

Table 4. Crosstabulation between nominal variables

\begin{tabular}{lcrrrrr}
\hline \multirow{2}{*}{ Nominal variables } & \multicolumn{2}{c}{ Domestic M\&As } & \multicolumn{2}{c}{ Cross-border } \\
\multicolumn{2}{c}{ M\&As } & \multicolumn{2}{c}{ Total } \\
\hline Unrelated acquisitions & 97 & $50.52 \%$ & 27 & $14.06 \%$ & $\mathbf{1 2 4}$ & $\mathbf{6 4 . 5 8 \%}$ \\
Related acquisitions & 35 & $18.23 \%$ & 33 & $17.19 \%$ & $\mathbf{6 8}$ & $\mathbf{3 5 . 4 2 \%}$ \\
\hline Total & $\mathbf{1 3 2}$ & $\mathbf{6 8 . 7 5 \%}$ & $\mathbf{6 0}$ & $\mathbf{3 1 . 2 5 \%}$ & $\mathbf{1 9 2}$ & $\mathbf{1 0 0 \%}$ \\
\hline
\end{tabular}

(Source: Authors' own processing, using SPSS 25.0)

As we notice in Table 4, the most acquisitions in Romania are included in domestic conglomerate acquisitions (97 transactions), although the mean of the stake purchased in unrelated acquisitions is much lower than the one purchased in related acquisitions (vertical or horizontal) (see Table 3). Given the opinion according to which the financial reasons conduct to conglomerate acquisitions, rather than the productivity ones (Nelson-Espeland \& Hirsch, 1990), the acquirers purchase an amount of stake which can bring economic benefits, but they don't consider acquiring a company as a whole or a controlling interest. In our case, both ANOVAs are significant $(\mathrm{p}<0.01)$, which means that we reject he null hypothesis (we validated 
the fact that there is a difference between the means, considering the DV as the numeric variable). Also, we calculated the strength of association between the two nominal variables using Cramer's phi coefficient $(\varphi=.276, p<0.01)$. The value of the coefficient reflects a good significant association between the relatedness of the companies involved in acquisitions and the national/international dimension of the concentration.

Table 5. Descriptive statistics for numeric variables

\begin{tabular}{lrrr}
\hline \multicolumn{1}{c}{ Values } & Final stake (\%) & Workforce ratio & Productivity ratio \\
\hline Minimum & 0.023 & 0 & 0 \\
Maximum & 100 & 1004.18 & 8687.1 \\
Mean & 54.80284 & 33.4241 & 64.5203 \\
Std. Deviation & 41.02613 & 105.6082 & 643.2524 \\
\hline No. of observations & 192 & 192 & 192 \\
\hline
\end{tabular}

(Source: Authors' own processing, using SPSS 25.0)

According to Table 5, the lowest value for workforce is 0 , which means that there are acquiring companies with 0 employees that acquired targets. The highest value is around 1.000 employees, which means that a large company acquired a small one, for diverse reasons (assets, innovative products or niche market). Also, there are companies that report 0 productivity, because they didn't report employees in the annual report approved for the year before the acquisition. The highest productivity ratio is 8,687.1 th EUR.

The values of the coefficients for the Pearson correlation is presented in Table 6 .

Table 6. Pearson Correlation coefficient for numeric variables

\begin{tabular}{|c|c|c|c|c|}
\hline \multicolumn{2}{|c|}{ Variables } & Stake (\%) & Workforce ratio & Productivity ratio \\
\hline \multirow{6}{*}{ 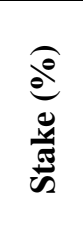 } & \multirow{2}{*}{ All acquisitions } & 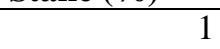 & $0.247^{* *}$ & 0.096 \\
\hline & & & 0.000 & 0.185 \\
\hline & \multirow{2}{*}{ Industry acquisitions } & 1 & $0.251^{* *}$ & 0.121 \\
\hline & & & 0.002 & 0.169 \\
\hline & \multirow{2}{*}{ Services acquisitions } & 1 & $0.317^{* *}$ & -0.040 \\
\hline & & & 0.008 & 0.759 \\
\hline \multirow{6}{*}{ 窇 } & \multirow{2}{*}{ All acquisitions } & $0.247^{* *}$ & 1 & -0.013 \\
\hline & & 0.000 & & 0.853 \\
\hline & \multirow{2}{*}{ Industry acquisitions } & $0.251^{* *}$ & 1 & -0.016 \\
\hline & & 0.002 & & 0.855 \\
\hline & \multirow{2}{*}{ Services acquisitions } & $0.317^{* *}$ & 1 & -0.132 \\
\hline & & 0.008 & & 0.294 \\
\hline \multirow{6}{*}{ 离 } & \multirow{2}{*}{ All acquisitions } & 0.096 & -0.013 & 1 \\
\hline & & 0.185 & 0.853 & \\
\hline & \multirow{2}{*}{ Industry acquisitions } & 0.121 & -0.016 & 1 \\
\hline & & 0.169 & 0.855 & \\
\hline & \multirow{2}{*}{ Services acquisitions } & -0.040 & -0.132 & 1 \\
\hline & & 0.759 & 0.294 & \\
\hline
\end{tabular}

Level of significance: * for $\mathrm{p}<0.05$ and $* *$ for $\mathrm{p}<0.01$ level.

(Source: Authors' own processing, using SPSS 25.0) 
According to information presented in Table 6, there isn't a significant correlation between the purchased stake and the productivity ratio, overall and by NACE main section, as established in Table 1 (sig. $=0.185, \mathrm{r}=0.096$ for all acquisitions, sig. $=$ $0.169, \mathrm{r}=0.121$ for industry acquisitions, sig. $=0.759, \mathrm{r}=-0.40$ service acquisitions), nor between workforce ratio and productivity ratio (sig. $=0.853, \mathrm{r}=-0.132$ for all acquisitions, sig. $=0.855, r=-0.016$ for industry acquisitions, sig. $=0.294, r=-0.40$ service acquisitions). On the other hand, the workforce ratio is significantly correlated with the dependent variable, with a level of significance under $1 \%$. This implies that the stake purchased by the acquirer is positively and significantly correlated with the report between the employees of the two companies, in the year before the acquisition (the number of employees reported the last annual financial statements that are approved to be published).

As well, high values of the Pearson correlation coefficient between the productivity ratio and workforce ratio, and also between the stake and the productivity ratio, for all the transactions and also split between industry and services, emphasize the possibility for collinearity between the independent variables. In order to check the multicollinearity, we present, in Table 7, the variance inflation factor (VIF). Once the values of the correlation coefficients have been estimated, to study the causality, Table 7 displays the estimations of the parameters for three regression models proposed for testing and validation, considering path a), per total and by major core activity (industry and services).

Table 7. Parameters estimation for the regression model for path a

\begin{tabular}{|c|c|c|c|}
\hline Variables & $\begin{array}{l}\text { All acquisitions } \\
\qquad \beta \text { (t-values) }\end{array}$ & $\begin{array}{c}\text { Acquisitions - } \\
\text { Industry } \\
\beta \text { (t-values) }\end{array}$ & $\begin{array}{c}\text { Acquisitions - } \\
\text { Services } \\
\beta \text { (t-values) }\end{array}$ \\
\hline Workforce ratio (Work_r) & $0.302^{* * *}(4.449)$ & $0.284^{* * *}(3.339)$ & $0.495^{\text {*** }}(4.563)$ \\
\hline $\begin{array}{l}\text { Productivity ratio } \\
(\text { Prod_r) }\end{array}$ & $0.104(1.563)$ & $0.117(1.430)$ & $0.100(.885)$ \\
\hline Relatedness $\left(R \_U n R\right)$ & $0.216^{* * *}(3.191)$ & $0.191^{* *}(2.247)$ & $0.355^{* * *}(3.177)$ \\
\hline$R^{2}$ & 0.174 & 0.158 & 0.335 \\
\hline Adjusted $R^{2}$ & 0.160 & 0.138 & 0.301 \\
\hline$F$ & $\begin{array}{c}\mathrm{F}(3,188)= \\
13.158 \\
\mathrm{p}=0.000\end{array}$ & $\begin{array}{c}\mathrm{F}(3,126)=7.890 \\
\mathrm{p}=0.000\end{array}$ & $\begin{array}{c}F(3,58)=9.749 \\
p=0.000\end{array}$ \\
\hline$N$ & 192 & 130 & 62 \\
\hline Multicollinearity tests & $\begin{array}{l}\text { Tolerance } \tau_{i}= \\
1-R_{i}^{2}=0.826 \\
\text { VIF }=1.001\end{array}$ & $\begin{array}{l}\text { Tolerance } \quad \tau_{i}= \\
1-R_{i}^{2}=0.842 \\
\mathrm{VIF}=1.001\end{array}$ & $\begin{array}{l}\text { Tolerance } \quad \tau_{i}= \\
1-R_{i}^{2}=0.665 \\
\text { VIF }=1.081\end{array}$ \\
\hline
\end{tabular}

(Source: Authors' own processing, using SPSS 25.0.) 
Table 7 present the influence of the independent variables on the mediation variable, all three models (all acquisitions, industry acquisitions and services acquisitions) being significant $(\mathrm{p}<0.01)$. Based on the data in Table 7 , all the variables have a positive influence on the national/international dimension of the acquisitions. The relatedness of the two companies positively and significantly influences the acquirers' choice for cross-border acquisitions, fact confirmed in Table 4, where the number of cross-border acquisitions between related companies is higher than the number of conglomerate acquisitions. Also, the acquirers with a high number of employees will purchase targets with a low number of employees, from another country. The productivity of the target company doesn't influence the choice for a domestic or a cross-border acquisition. The workforce ratio and the relatedness are positively and significantly influence the choice for cross-border acquisitions in the case of all the acquisitions in the sample, but also in the case of industry and services acquisitions. The predictors account for the highest variance of the dependent variable $\left(R^{2}=0.335\right)$ in the case of services acquisitions.

Table 8 presents the estimation of the parameters of the proposed models for the paths $\mathrm{b}$ and $\mathrm{b} \times \mathrm{c}$, considering the explanation in Figure 1. According to Table 8, the fact that the companies have related core activities (considering the first 3 digits of the NACE main code), which makes them either vertical or horizontal acquisitions, have a positive and significant influence on the final stake purchased. Thus, an acquirer will purchase a higher stake if the target company has related activities, fact that is also confirmed by the information presented in Table 3 (the mean stake purchased in related acquisitions is $73.39 \%$, compared to the one purchased in conglomerate acquisitions, which is $44.61 \%$ ). Also, the workforce ratio, calculated using the number of employees reported by the acquirer and the target in the last annual report before the deal took place, have a positive and significant influence on the final stake, which means that the larger the acquirer compared to the target, the higher the investment in the acquired company. The productivity of the acquirer compared to the target has a positive, but not significant influence on the stake, which means that the volume of revenues of the target, in the year before the acquisition, compared to those of the acquirer, reported to the number of employees, doesn't influence the final stake. In case of the industry acquisitions, the only significant variable is the relatedness, which means that the acquirers are purchasing higher stakes in companies in the same field or related, no matter the number of employees or their revenues. 
Table 8. Parameters estimation for the hierarchical regression model for paths $\mathbf{c}$ and $\mathrm{b} \times \mathrm{c}$

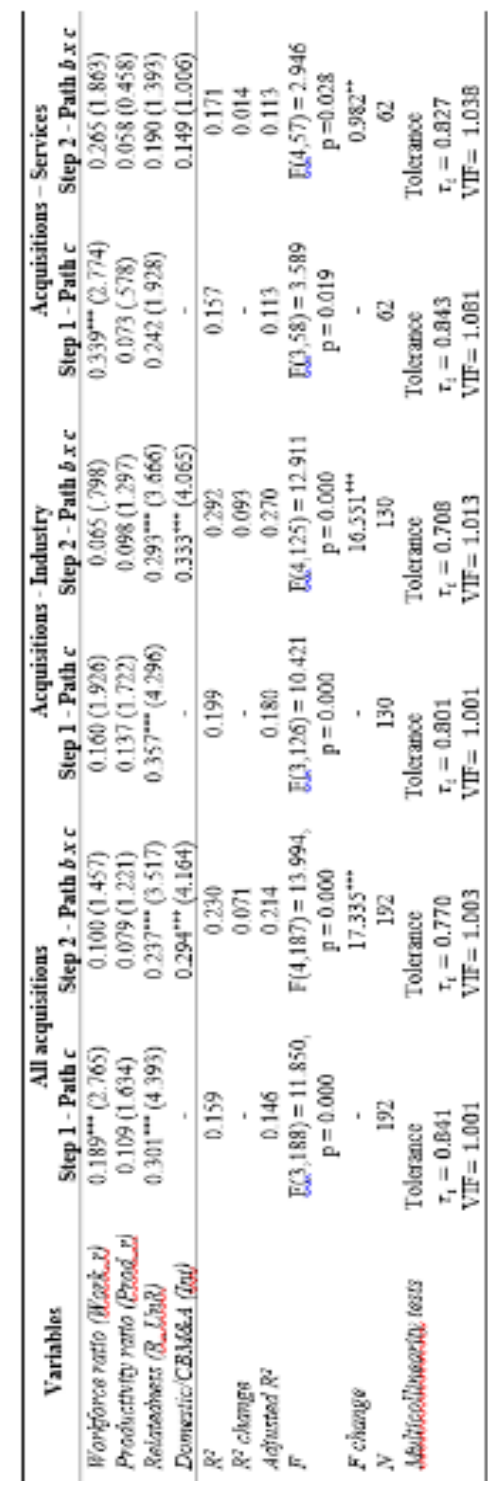

Level of significance: $* \mathrm{p}<0,1 ; * * \mathrm{p}<0,05 ; * * * \mathrm{p}<0,01$.

(Source: Authors' own processing, using SPSS 25.0.)

The capacity of the model to predict the variance in the dependent variable is the highest in the industry sector $\left(\mathrm{R}^{2}=0.199\right)$. In services acquisitions, the independent variable that is significant and positively influence the investment in target company is the workforce, which means the large acquirers purchase high stakes in a small target company (considering the number of employees as measurement indicator). 
We have to acknowledge the fact that the mediation variable in all three cases improves the proposed model to predict the variance of the DV ( $\mathrm{R}^{2}$ change) in Table 8.

When adding the mediation variable to the model (paths b \& c), the predictors, workforce ratio, productivity ratio, relatedness and the national/international dimension of the acquisition, account for $23 \%$ of the variance of the dependent variable (the final stake) in the case of all the acquisitions in the sample, for $29.2 \%$ in the case of industry acquisitions and only $17 \%$ in the case of services acquisitions.

\section{Conclusions}

Romania is a market with potential, a strategic location, and a favorable business climate as the International Trade Administration (2018) states. Despite its weaknesses, it doesn't have a significant history regarding M\&As, but the year of the adherence to the European Union was a turning point. After 2007, it became a more active and attractive market for companies, local and abroad, fact that led to the number of transactions almost tripling from 184 to 521 transactions, in the 20072018 period of time.

The fact that the acquisitions are not regulated by a specific legislation in Romania, like mergers are, makes it difficult to identify them, being just a purchase of an investment in another company's capital. Because we identified 192 acquisitions which involved at least one Romanian company, in either the position of the acquirer or/and the target, we identified some determinants of the stake purchased by the acquiring company in the target entity. In order to detail our analysis, we test and validate our hypotheses for all acquisitions (192 transactions) and, then, for industry acquisitions (130 transactions) and services acquisitions (62 transactions).

The fact that the companies have related core activities (considering the first 3 digits of the NACE main code), which makes them either vertical or horizontal acquisitions, have a positive and significant influence on the final stake purchased. Thus, an acquirer will purchase a higher stake if its activities are related to the ones of the target company, which is also confirmed by the mean stake purchased in related acquisitions (73.39\%), compared to the one purchased in conglomerate acquisitions (44.61\%). Also, the workforce ratio has a positive and significant influence on the final stake, which means that the larger the acquirer compared to the target, the higher the investment in the acquired company. The productivity of the acquirer compared to the target has a positive, but not significant influence on the stake, which means that the volume of revenues of the target, in the year before the acquisition, compared to those of the acquirer, reported to the number of employees, doesn't influence the final stake. In case of the industry acquisitions, the 
only significant variable is the relatedness, which means that the acquirers are purchasing higher stakes in companies in the same filed or related, no matter the number of employees or their revenues. In services acquisitions, the independent variable that is significant and positively influence the investment in target company is the workforce, which means the large acquirers purchase high stakes in small target company.

One of the limits of the study is the relatively small number of transactions in our sample (192 acquisitions). The fact that many involved companies (acquirers and targets) reported zero employees in the year prior to the acquisition made the calculation of productivity ratios and workforce ratios impossible. Second, many companies involved in acquisitions, according to Zephyr database, were missing the financial data in Orbis database. For future research, we intend to analyze the influence of macroeconomic conditions of the involved companies' residence countries, in the year of the acquisition, given the fact the information from Zephyr database is more complete when considering the M\&As.

\section{Acknowledgement}

This project is funded by the Ministry of Research and Innovation within Program 1 - Development of the national RD system, Subprogram 1.2 - Institutional Performance - RDI excellence funding projects, Contract no.34PFE/19.10.2018.

\section{References}

Aevoae, G.M. \& Georgescu,I. (2019) "The determinants of cross-border acquisitions: evidence from Romania", Revista Audit financiar, Vol. 17, No. 2(154): 232-244.

Alegre, I., Mas-Machuca, M. \& Berbegal-Mirabent, J. (2016) "Antecedents of employee job satisfaction: Do they matter?", Journal of Business Research, Vol. 69, No. 4: 1390-1395.

Andrade, G., Mitchell, M. \& Stafford, E. (2001) "New evidence and perspective on mergers", Journal of Economic Perspectives, Vol. 15, No. 2: 103-120.

Blanckard, K. \& Gibson, J. (2002) Capitalizing on Conflict: Strategies and Practices for Turning Conflict to Synergy in Organizations, Palo Alto, California: Davies-Black Publishing.

Bouchikhi, H. \& Kimberly, J. (2012) "Making mergers work", MIT Sloan Management Review, Vol. 54, No. 1: 63-70.

Brătianu, C. \& Anagnoste, S. (2011) "The role of transformational leadership in mergers and acquisitions in emergent economies", Management and Marketing, Vol. 6, No. 2: 31-326. 
Canina., L., Kim, J.Y. \& Ma, Q. (2010) "What do we know about M\&A success? A research agenda for the lodging industry", Cornell Hospitality Quarterly, Vol. 51, No. 1: 81-101.

Cartwright, S. \& Schoenberg, R. (2006) "Thirty years of mergers and acquisitions research: recent advances and future opportunities", British Journal Of Management, Vol. 17, No. S1: S1-S5

Casares Field, L. \& Karpoff J., M. (2002), "Takeover defenses of IPO firms", The Journal of Finance, Vol. 57, No. 5:1857-1889.

Cernat-Gruici, B., Constantin, L.G. \& Iamandi, I.E. (2010) "An overwiew on the Romanian M\&A Market during the recent financial crisis", The Romanian Economic Journal, Vol. 13, No. 37: 167-178.

Conyon, M., Girma, S., Thompson, S. \& Wright, P. (2000) “The impact of mergers and acquisitions on company employment in the United Kingdom", Research Paper, Centre for Research on Globalization and Labour Markets, available online at https://www.nottingham.ac.uk/gep/documents/papers/2000/00 05.pdf, date of consultation February $15^{\text {th }}, 2019$.

Danbolt, J. \& Maciver, G. (2012) "Cross-border versus domestic acquisitions and the impact on shareholder wealth", Journal of Business Finance \& Accounting, Vol. 39, No. 7-8: 1028-1067.

Denison, D., Adkins, B. \& Guidroz, A. (2011) "Managing cultural integration in cross-border mergers and acquisitions", Advances in Global Leadership, Vol. 6: $95-115$.

Di Laurea, T. (2014) "Mergers and acquisitions. An analysis on Italian companies acquired in 2011", Università Ca' Foscari Venezia, available online at http://dspace.unive.it/handle/10579/5728, date of consultation March $1^{\text {st }}$, 2019.

Easterbrook, F., H. \& Fischel, D., R. (1991) "The economic structure of corporate law", Harvard University Press, Cambridge, Massachusetts

Easterbrook, F.H. (1984) 'Managers' discretion and investors' welfare: theories and evidence", Delaware Journal of Corporate Law, 9: 540-571.

European Commission (2013), "Mergers. Overview", available online at http://ec.europa.eu/competition/mergers/overview_en.html, date of consultation March $22^{\text {nd }}, 2019$.

Ficery, K., Herd, T. \& Pursche, B. (2007) "Where has all the synergy gone? The M\&A puzzle", Journal of Business Strategy, Vol. 28, No. 5: 29-35. 
Filip, A., Lobo, G., Paugam, L. \& Stolowy, H. (2018) "Disclosures about intangible resources in M\&A press releases and quality of the deal", available online at https://pdfs.semanticscholar.org/462d/94250af84ef45dde06b23a8375acbf49a bb1.pdf

Fraser, D.R. \& Zhang, H. (2009) "Mergers and long-term corporate performance: evidence from cross-border bank acquisitions", Journal of Money, Credit and Banking, Vol. 41, No. 7: 1503-1513.

Frazier et al., Tix, A. \& Barron. K. (2004) "Testing moderator and mediator effects in counseling psychology research", Journal of Counseling Psychology, Vol. 51, No. 1: 115-134.

Harrigan, K., DiGuardo, M.C. \& Cowgill, B. (2016) "Multiplicative-innovation synergies: test in technological acquisitions", Journal of Technological Transformations, Vol. 42, No. 5: 1212-1233.

International Trade Administration (2018) "Romania Country Commercial Guide", available online at https://www.export.gov/article?id=Romania-MarketOverview, date of consultation March 22 2019.

Irfan, M. (2010) "The role of executives in hostile takeover attempts", Journal of Economic Interaction and Coordination, Vol. 6, No. 1: 29-40.

Jensen, M. \& Ruback, R (1983) "The market for corporate control: The scientific evidence", Journal of Financial Economics, Vol. 11, No. 1-4: 5-50.

King, D., Dalton, D., Daily, C. \& Covin, J. (2004) "Meta-analyses of postacquisition performance: Indication of unidentified moderators", Strategic Management Journal, 25: 187-200.

Knoeber, C. (1986) "Golden parachutes, shark repellents, and hostile tender offers", The American Economic Review, Vol. 76, No. 1: 155-167.

Kumar, R. \& Suhas, K.M. (2010) "An analytical study on value creation in Indian bank mergers", Afro-Asian Journal of Finance and Accounting, Vol. 2, No. 2: 107-134.

Lehmann, E. E. \& Schwerdtfeger, M. T. (2016) "Evaluation of IPO-firm takeovers: an event study", Small Business Economics, Vol. 47, No. 4: 921-938.

Moeller, S. \& Schlingemann, J. (2005) "Global diversification and bidder gains: A comparison between cross-border and domestic acquisitions", Journal of Banking \& Finance, Vol. 29, Nr. 3: 533-564.

Nelson Espeland, W. \& Hirsch, P. (1990) "Ownership changes, accounting practice and the redefinition of the corporation", Accounting, Organizations and Society, Vol. 15, No. 1-2: 77-96.

Nitzan, J. (2001) "Regimes of differential accumulation: mergers, stagflation and the logic of globalization", Review of International Political Economy, Vol. 8, No. 2: 226-274.

Norbäck, P.J. \& Persson, L. (2008) "Globalization and profitability of cross-border mergers and acquisitions", Economic Theory, Vol. 35, No. 9: 241-266. 
O'Brien, R. (2007) "A caution regarding rules of thumb for variance inflation factors", Quality \& Quantity, Vol. 41, No. 5: 673-690.

Offenberg, D. \& Pirinsky, C. (2015) "How do acquirers choose between mergers and tender offers?", Journal of Financial Economics, Vol. 116, No. 2: 331-348.

Pop, D. (2006) "M\&A market in transitions economies: Evidence from Romania", Emerging Markets Review, Vol. 7, No. 3: 244-260

Rani, N., Yadav, S.S. \& Jain, P.K. (2015) "Financial performance analysis of mergers and acquisitions: evidence from India", International Journal of Commerce and Management, Vol. 25, No. 4: 402-423.

Rozen-Bakher, Z. (2018) "The trade-off between synergy success and efficiency gains in M\&A strategy", EuroMed Journal of Business, Vol. 13, No. 2: 163-184.

Sarala, R. (2010) "The impact of cultural differences and acculturation factors on post-acquisition conflict", Scandinavian Journal of Management, Vol. 26, No. 1: 38-56.

Sarala, R. \& Vaara, E. (2009) "Cultural differences, convergence, and crossvergence as explanations of knowledge transfer in international acquisitions", Journal of International Business Studies, Vol. 41, No. 8: 1365-1390.

Schuster, L. \& Hunter, M. (2015) "Human Resources Strategy and Change: Essentials of Mergers, Acquisitions, and Joint Ventures", Handbook of Human Resources Management: 1-20.

Shleifer, A. \& Summers, L. (1988) Breach of Trust in Hostile Takeovers, in Auerbach, A. (1988), Corporate Takeovers: Causes and Consequences, Chicago: University of Chicago Press.

Stahl, G. K. \& Voigt, A. (2005) "Impact of cultural differences on mergers and acquisition performance: A critical research review and an integrative model", Advances in Mergers and Acquisitions, Vol. 4: 51-82.

Suzuki, K. (2015) "Estimating private benefits of control from stock price changes around the announcement of tender offer bid (TOB)", Public Policy Review, Vol.11, No.3: 411-426.

Warter, I. \& Warter, L. (2014) "Latest trends in mergers and acquisitions research. The new pattern of globalization", Bulletin of the Polytechnic Institute, Vol. 64, No. 2: 25-43.

Weber, Y., Tarba, S. \& Reichel, A. (2011) "A model of the influence of culture on integration approaches and international mergers and acquisitions performance", International Studies of management and Organization, Vol. 41, No. 3: 9-24.

Wood, R. E., Goodman, J. S., Beckmann, N. \& Cook, A. (2007) "Mediation testing in management research", Organizational Research Methods, Vol. 11, No. 2: 270-295. 